\title{
Rediscovery of the wild pig Sus bucculentus
}

$S^{u s}$ bucculentus, a species of wild pig $\checkmark$ from Indochina, was described more than a century ago' but has not been reported since and has remained in the 'mystery' category. We here report its rediscovery in the Annamite Range in Laos, an area which is becoming famous for the discovery of new and previously undescribed large mammals ${ }^{2}$.

Sus bucculentus was described from two skulls $^{1}$ from Vietnam, and was claimed to differ from the much commoner $S$. scrofa (the widespread Eurasian wild pig from the same area) in skull characters and in the form of the lower canine of the male, in which it was said to resemble the warty pig (S. verrucosus) of Java. The whereabouts of the type specimens was unknown until recently. In July 1996, the type male skull was found by one of us (C. P. G.), unregistered but bearing an identification in Père Heude's handwriting, in the collection of the Institute of Zoology, Academia Sinica, Beijing. It is inscribed "Bienhoa", an important colonial centre of the former French Indochina, and so doubtless a place of export rather than a locality. It does resemble S. verrucosus in many ways (deep preorbital fossa, elongated facial skeleton, high occipital crest, flat dorsal outline to the braincase and very long palate), but the canine is not like S. verrucosus as claimed in the original description ${ }^{1}$. It has large premolars compared to the molars, in contrast with both S. scrofa and S. verrucosus; a primitive condition.

A new specimen of $S$. bucculentus, a partial skull of a juvenile male, was obtained from indigenous hunters in the Annamite Range, Laos, in January 1995 by two of us (G. B. S. and K. K.; Fig. la). The locality of the new skull is Ban Ni Ghiang, $18^{\circ} 19^{\prime} \mathrm{N}$, $104^{\circ} 44^{\prime} \mathrm{E}$, a village on the Nam Gnouang. This can be taken as the first definite

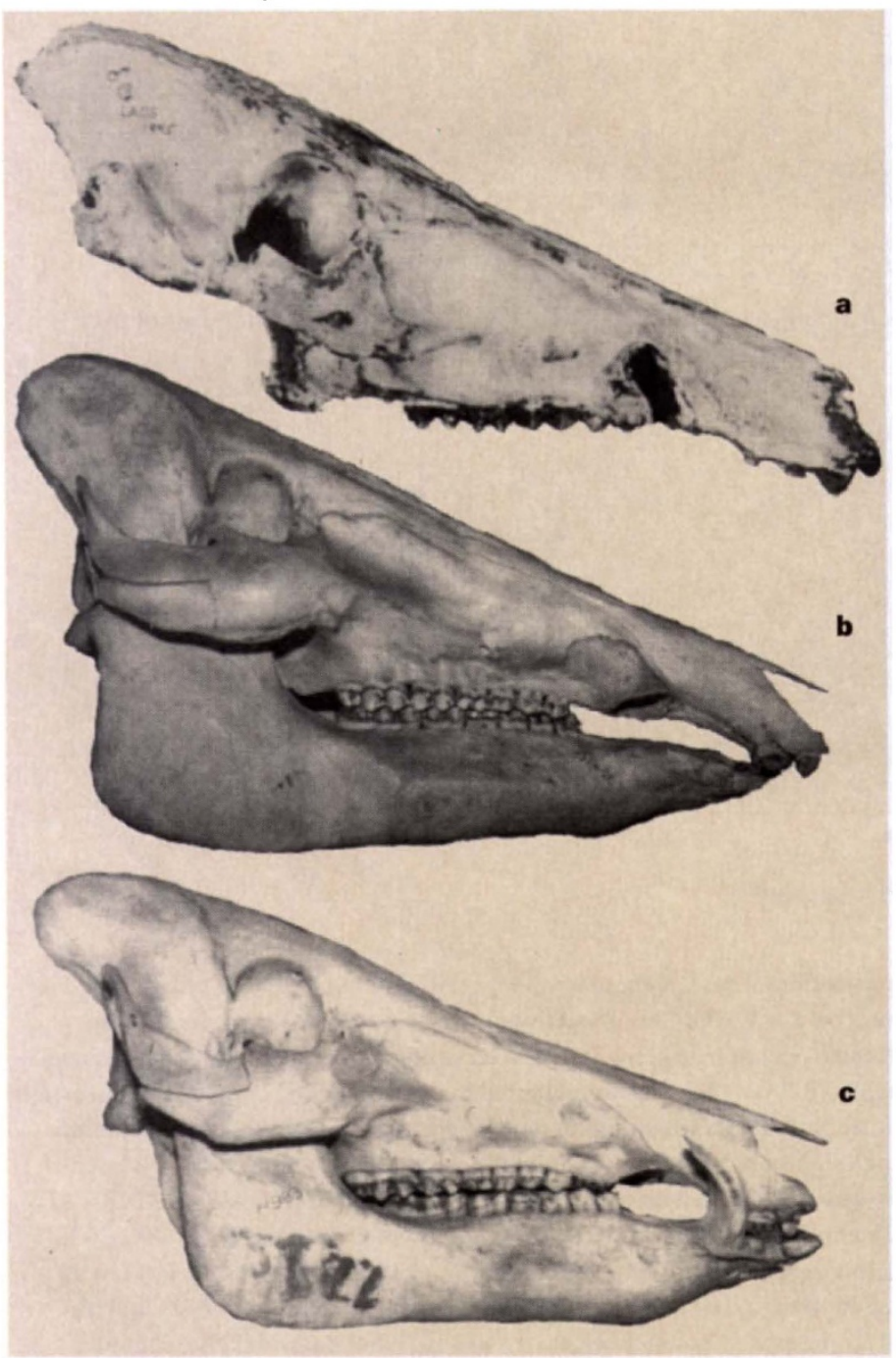

locality for the species. The morphology is identical to that of the type skull (Fig. 1b) except for age differences.

Muscle tissue adhering to the new skull was used to extract and sequence a 327-base fragment of the $12 \mathrm{~S}$ ribosomal mitochondrial gene, which was compared with material from a local wild S. scrofa (Fig. 1c) and a local domestic pig. The latter two were identical, but differed at 24 sites from the specimen of $S$. bucculentus. For a gene as conserved as the $12 S$ ribosomal gene $e^{4}$, a difference as large as this is remarkable.

The rediscovery of this species is significant. It is another representative of a steadily enlarging clique of primitive large mammals whose ranges are more-or-less restricted to the Annamite Range ${ }^{2}$, which lies along the central part of the Laos/Vietnam border. Here it lives alongside the much more widespread common wild pig, S. scrofa. This rugged region of igneous rocks, with localized karst cliffs and domes, still has large tracts of montane evergreen broad-leafed forest with an understorey of bamboo, palms and saplings, broken by swidden plots and regenerating forest.

The primitive status of S. bucculentus recalls two other recently described Annamite mammals: the bovid Pseudoryx nghetinhensis, which has been interpreted as alternatively a divergent member of the bovine (ox/buffalo/kudu) clade ${ }^{3}$ or the sister group of the caprine (sheep/goat/ chamois) clade 5 ; and the cervid Megamuntiacus vuquangensis, which is the sister group of the diverse genus Muntiacus (muntjac deer) $)^{3}$. These conclusions underline the significance of the Annamites as a biotically unique region where primitive taxa, long extinct elsewhere, have been able to survive into the late twentieth century.

\section{Colin P. Groves}

Department of Archaeology and Anthropology,

Australian National University,

Canberra, ACT 0200 ,

Australia

colin.groves@anu.edu.au

George B. Schaller

George Amato

Wildlife Conservation Society,

Bronx, New York 10460, USA

Khamkhoun Khounboline

Department of Forestry,

Vientiane,

Lao People's Democratic Republic margin of the braincase is straight, not convex and the occipital crest is higher; and the premolars are long compared to the molars.

\footnotetext{
1. Hcude, P.-M. Mémoires d'Histoire Naturelle de l'Empire

Chinois, 2, 85-115, 212-222; 4, 113-133 (Musée du Zikawel, Shanghai, 1892).

2. Schaller, G. B. \& Rabinowitz, A. Oryx 29, 107-114 (1995).

3. Dung, V. V. et al. Nature $363,443-445$ (1993).

4. Amato, G. \& Galesy, J. in Molecular Approaches to Ecology and Evolution (eds Schierwater, B. Streit, B., Vagner, G. \& DeSalle, R.) (Birkhauser, Basel 1994).

5. Thomas, H. Mammalia 58, 453-481 (1994).

6. Groves, C. P. \& Dawson, S. Mammalia (in the press).
} 